\title{
Wpływ oddziaływania paliw etanolowych E20 na degradację oleju silnikowego
}

Podstawowym celem podjętych badań było określenie wpływu paliw etanolowych zawierających $20 \%$ (V/V) bioetanolu na procesy degradacji smarowego oleju silnikowego, monitorowane za pomocą wybranych parametrów fizykochemicznych. Na obiekt badań, ze względu na właściwości lepkościowe i jakościowe, wytypowano olej silnikowy o klasie lepkości SAE 5W-30 i klasie jakości ACEA A5/B5 przeznaczony do smarowania silników samochodowych o zapłonie iskrowym typu flex-fuel. W ramach projektu przeprowadzono dwa testy na stanowisku silnikowym typu flex-fuel z zapłonem iskrowym zasilanego dwoma paliwami, skomponowanymi z:

- $\quad 80 \%(V / V)$ bazowej benzyny silnikowej $+20 \%(V / V)$ bioetanolu pierwszej generacji + pakietu dodatków uszlachetniających opracowanego w Instytucie Nafty i Gazu - Państwowym Instytucie Badawczym,

- $80 \%(V / V)$ bezołowiowej benzyny silnikowej (handlowa, uszlachetniona pakietem dodatków przez producenta) + $20 \%(V / V)$ bioetanolu pierwszej generacji.

Stopień degradacji smarowego oleju silnikowego był określany zarówno w czasie trwania prób silnikowych (próbki pobrane po 200 h pracy silnika), jak również po zakończeniu jego eksploatacji (po 400 h pracy silnika, która była zrealizowana w czasie około 2 miesięcy).

Słowa klucze: paliwo etanolowe, olej silnikowy, degradacja.

\section{The influence of E20 ethanol fuels on engine oil degradation}

The basic aim of this study was to determine the effect of fuel ethanol containing $20 \%(V / V)$ of bioethanol on the degradation processes of lubricating engine oil, monitored by selected physicochemical parameters. As an object of study, because of its viscosity and quality properties, was selected the SAE 5W-30 viscosity grade and ACEA A5/B5 quality grade engine oil, which is suitable for the lubrication of spark ignition Flex Fuel automobile engines. Within the project, two bench tests were carried out on the spark ignition Flex Fuel engine powered by two kinds of fuels composed of:

- $\quad 80 \%(V / V)$ of base gasoline $+20 \%(V / V)$ of first-generation bioethanol + additive package designed in the Oil and Gas Institute - National Research Institute,

- $80 \%(V / V)$ of unleaded gasoline (commercial, ennobled by the manufacturer with additive package $)+20 \%(V / V)$ of first-generation bioethanol.

The degree of degradation of lubricating engine oil was determined during both engine bench tests (samples obtained after 200 hours of engine work), as well as at the end of its exploitation (after $400 \mathrm{~h}$ of work).

Key words: ethanol fuel, engine oil, degradation.

\section{Wstęp}

Olej smarowy stanowi jedno z ogniw łańcucha, na który składają się: silnik, układ oczyszczania spalin i paliwo. W czasie eksploatacji olej silnikowy narażony jest na działanie różnych czynników prowadzących do stopniowej utraty jego właściwości użytkowych i eksploatacyjnych, określonych za pomocą różnych parametrów, których zmiany mogą postępować ze zróżnicowaną prędkością. Rozcieńczenie oleju smarowego paliwem skutkuje początkowo stopniową zmianą jego lepkości-domieszka w ilości około $10 \div 15 \%$ paliwa powoduje rozcieńczenie oleju do wartości krytycznej z punktu widzenia funkcji smarowania (lepkość kinematyczna w temperaturze $100^{\circ} \mathrm{C}$ wynosi około $6 \mathrm{~mm}^{2} / \mathrm{s}$ ), co prowadzi do zerwania filmu smaro- 
wego, wystąpienia tarcia granicznego, nawet suchego zamiast płynnego lub co najmniej półpłynnego, stwarzając zagrożenie dla pracy silnika [15]. W konsekwencji może to powodować wzmożone procesy zużycia elementów roboczych silnika (m.in. uszkodzenie lub zniszczenie warstwy ślizgowej panewek głównych i korbowodowych, zacieranie czopów w panewkach, uszkodzenie warstwy honowanej na powierzchni tulei cylindrowych oraz zatarcie tłoków w cylindrach) [15].

Zanieczyszczenia oleju smarowego twardymi cząstkami stałymi, pochodzącymi ze zużycia elementów silnika lub przedostającymi się wraz z zasysanym do silnika powietrzem na skutek uszkodzenia filtra, osadzają się na miękkiej powierzchni panewek.

Dalsza eksploatacja prowadzi do przedwczesnego zużywania się panewek - w wyniku ścierania - i współpracujących z nimi czopów oraz innych powierzchni. Powyższe procesy dodatkowo zwiększają intensywność powstawania produktów kwaśnych w stopniowo degradującym się oleju, powodując pojawienie się ognisk korozji na wewnętrznych elementach silnika $[15,17]$.

Zmiany właściwości użytkowych i eksploatacyjnych oleju silnikowego mogą być również wynikiem degradacji chemicznej na skutek zachodzenia niekorzystnych reakcji chemicznych pomiędzy komponentami oleju i składnikami pakietu dodatków uszlachetniających pochodzących z paliwa lub zawartymi w nim biokomponentami. Podwyższona w benzynach zawartość związków tlenowych i olefin sprzyja powstawaniu nierozpuszczalnych szlamów w oleju smarowym, zwłaszcza w połączeniu ze stosowaniem w silniku recyrkulacji gazów spalinowych. Procesy te zachodzą pod wpływem oddziaływania na olej silnikowy czynników chemicznych, do których zaliczamy między innymi gazy spalinowe, przedostające się do miski olejowej silnika w czasie jego pracy. Procesy te są przyspieszane na skutek ciągle rosnącego obciążenia cieplnego i mechanicznego elementów w nowo konstruowanych silnikach o znacznie mniejszych pojemnościach i o większej mocy - tzw. downsizing [15, 17].

Jednym z problemów wynikających z eksploatacji paliwa etanolowego jest przedostawanie się etanolu oraz towarzyszącej mu wody do smarowego oleju silnikowego. W konsekwencji tworzą się substancje o charakterze kwaśnym. Proces ten nie wymaga wysokiej temperatury, w przeciwieństwie do tworzenia się kwasów w procesach utleniania i nitratacji. Niespalony etanol, który dostał się do oleju silnikowego, może reagować z tlenem, tworząc kwas octowy. Obecność kwasu octowego i wody w smarowym oleju silnikowym niesie za sobą wysokie ryzyko korozji silnika. Procesy korozyjne są szczególnie niebezpieczne dla elementów silnika wykonanych z metali miękkich. Zakwaszenie smarowego oleju silnikowego ograniczane jest do czasu zachowania odpowied- niej rezerwy alkalicznej (całkowitej liczby zasadowej) lub do momentu utrzymania zawartości dodatków uszlachetniających na odpowiednim poziomie [1].

Niespalone w silniku paliwo etanolowe może przyczyniać się do tworzenia się osadów w misce olejowej, których ilość jest zależna od obecności olefin w benzynie silnikowej. Olefiny mają tendencję do polimeryzacji w niskich temperaturach, zwłaszcza w obecności wytworzonego kwasu octowego. Skutkuje to powstawaniem osadów typu żywice. Tworzone w ten sposób żywice początkowo są rozproszone w oleju dzięki obecności dyspergatorów. Jednak ze względu na swą masę cząsteczkową aglomerują w misce olejowej, zmieniając lepkość smarowego oleju silnikowego. W konsekwencji ich obecność może prowadzić do zatykania kanałów smarowych i ograniczenia przepływu oleju smarowego przez układ smarowania silnika [14].

Innym rodzajem osadów, które mogą się tworzyć w wyniku eksploatacji paliwa etanolowego w oleju silnikowym, są tzw. białe osady. W warunkach zimowych oraz przy eksploatacji pojazdu na krótkich odcinkach (konieczność częstego rozgrzewania silnika) dochodzi do dużego rozcieńczenia silnikowego oleju smarowego etanolem $(>15 \%)$, a także - w wyniku jego właściwości higroskopijnych - wodą (>20\%). Obecność tych składników powoduje powstanie stabilnej emulsji, która pojawia się w postaci białych osadów. Istnieje pewien poziom ilości etanolu w misce olejowej, powyżej którego następuje rozdział faz. Wówczas mieszanina etanol-woda zostaje wytrącona jako warstwa dolna. Powstała w oleju emulsja etanol-woda może być stabilna przez około 18 godzin, a rozdział faz może trwać kilka tygodni [15]. Efekt ten prowadzi do zwiększenia ryzyka blokowania filtrów olejowych, zwłaszcza w okresie zimowym, gdy możliwe jest zamarznięcie emulsji. W wyniku tego zjawiska znacznie pogarsza się pompowalność oleju, a czas potrzebny na dostarczenie oleju smarowego do kluczowych złożeń ruchomych elementów roboczych silnika będzie się wydłużał po uruchomieniu zimnego silnika. Prowadzi to do powstania zagrożenia występowania tarcia granicznego, a nawet półsuchego, prowadzącego do zatarcia elementów ruchomych $[2,4,8,14]$.

Etanol jest również substancją, która nie miesza się całkowicie ze środkiem smarowym. Właściwość ta zwiększa ryzyko wzrostu stopnia zużycia silnika, zwłaszcza w przypadku tych jego części, dla których wymagana jest wysoka lepkość dynamiczna HTHS (high temperature high shear rate). Ze względu na charakterystykę rozpuszczalności etanolu potencjalnie może on usuwać cząsteczki z powierzchni metalu, a tym samym zmniejsza grubość filmu olejowego pomiędzy oddziałującymi powierzchniami. W konsekwencji nie jest zapewnione całkowite pokrycie chropowatości współpracujących powierzchni, a tym samym wzrasta ich zużycie na skutek występowania tarcia granicznego lub półsuchego. 
Zwiększenie zawartości żelaza i glinu pod wpływem zużycia elementów silnika jest obserwowane w przypadku stosowania benzyny silnikowej E85 w połączeniu z niską temperaturą pracy silnika. Dodatkowo w silnikach z bezpośrednim wtryskiem paliwa może dochodzić do wzrostu stężenia niespalonego etanolu, który będzie oddziaływać na cienką warstwę filmu olejowego węzła ciernego, powodując jej wymywanie, co zintensyfikuje procesy zużycia ściernego tulei i pierścieni tłokowych $[3,11,14]$.
Rozcieńczenie smarowego oleju silnikowego etanolem może być szczególnie duże w przypadku, kiedy silnik jest często uruchamiany w warunkach zimowych i pracuje na krótkich odległościach. W temperaturach poniżej $-10^{\circ} \mathrm{C}$ podczas takiej eksploatacji ilość etanolu przedostającego się do oleju smarowego może sięgnąć nawet kilkuset mililitrów [15]. Odparowanie etanolu z oleju smarowego możliwe jest podczas normalnych warunków eksploatacji, nie powoduje przy tym żadnych uszkodzeń silnika.

\section{Kryteria oceny oraz metody badań właściwości oleju silnikowego}

Bezawaryjna praca współczesnych silników spalinowych zasilanych biopaliwem wymaga bardzo dobrego smarowania, w tym kompatybilności pakietów dodatków uszlachetniających te produkty. Olej silnikowy stanowi jeden z elementów konstrukcyjnych, który w coraz większym stopniu wpływa na właściwości użytkowe silnika, jego osiągi, niezawodność i trwałość oraz na wielkość i toksyczność emisji toksycznych składników spalin. Jego skład staje się coraz bardziej złożony, a zatem wymaga wnikliwych badań laboratoryjnych, silnikowych i eksploatacyjnych $[3,10]$.

Postęp w zakresie technologii produkcji olejów silnikowych, jaki nastąpił w ostatnim czasie, wiąże się głównie z działaniami mającymi na celu zmniejszenie szkodliwego wpływu na środowisko oraz wydłużenie czasu eksploatacji [5]. Od kilkunastu lat obecny jest trend rozwoju energooszczędnych olejów silnikowych, a oczekiwania użytkowników dotyczą przede wszystkim żywotności silnika, bezawaryjności pracy i wydłużonego przebiegu eksploatacyjnego.

Ze względu na skład grupowy oleju silnikowego, będącego mieszaniną związków o różnych właściwościach fizycznych i chemicznych, oraz na warunki jego użytkowania istnieje szeroka grupa związków, które mogą się tworzyć w czasie eksploatacji oleju, jednocześnie zmniejszając jego przydatność do dalszego spełniania jego funkcji. Wydzielające się w czasie pracy silnika ciepło oraz kontakt z paliwem i produktami jego spalania, przy nieograniczonym dostępie tlenu z powietrza, przyczyniają się do degradacji olejów silnikowych, głównie węglowodorów [11]. Towarzyszące temu zjawisku inne przemiany chemiczne przyczyniają się do degradacji dodatków uszlachetniających, wprowadzanych do oleju smarowego w celu poprawy jego właściwości fizykochemicznych. Zatem w czasie eksploatacji oleju silnikowego obserwuje się zmiany jego charakteru chemicznego, jak również jego jakości.

Stopniowe zmiany składu chemicznego oleju smarowego są zjawiskiem normalnym. Gwałtowne zmiany jednego lub kilku parametrów jakościowych stanowią podstawę do podjęcia decyzji o wymianie oleju silnikowego. Olej silni- kowy w tłokowym silniku spalinowym, pełniąc swoje funkcje, ulega procesom degradacji, które mają związek z [7, 11]:

- rodzajem stosowanego paliwa,

- konstrukcją silnika,

- warunkami eksploatacji silnika, np. krótkie odcinki jazdy (wielokrotne rozgrzewanie i chłodzenie silnika), jazda w korkach ulicznych (jazda w warunkach określanych popularnie jako stop-and-go), wydłużona praca silnika na biegu jałowym, częste uruchamianie silnika w niskich temperaturach, eksploatacja samochodu w terenie górzystym (naprzemienne gwałtowne przegrzewanie i chłodzenie silnika), kondensacja wody na wewnętrznych elementach silnika (prowadzi do tworzenia emulsji z olejem smarującym) [10].

W ostatnich latach opracowuje się i wykorzystuje w praktyce coraz więcej procedur monitorowania zmian właściwości silnikowego oleju smarowego w czasie eksploatacji. Ma to na celu zapewnienie wymaganych właściwości użytkowych i eksploatacyjnych oleju smarowego poprzez weryfikację czasu pomiędzy jego wymianami, w zależności od warunków eksploatacji ściśle związanych z ilościowymi i jakościowymi procesami degradacji środka smarowego. Dzięki temu można nie tylko zagwarantować bezpieczną i niezawodną pracę silnika, ale również kontrolować optymalne warunki pracy z punktu widzenia współdziałania z olejem silnikowym, którego zmiany właściwości są wypadkową warunków eksploatacji pojazdu i rodzaju stosowanego paliwa.

Zasadniczo wyróżnia się trzy uzupełniające się obszary oceny zmian właściwości oleju silnikowego w czasie eksploatacji:

1) Ocena ilościowa oraz jakościowa zmian zawartości pierwiastków pochodzących ze zużycia i zanieczyszczeń. W tym przypadku próbki oleju smarowego pobierane są z dolnej (poniżej wału korbowego) i górnej części silnika. Ocenia się je pod kątem zawartych w nich twardych cząstek metalicznych, na podstawie oznaczenia następujących pierwiastków: $\mathrm{Cu}, \mathrm{Fe}, \mathrm{Cr}, \mathrm{Pb}, \mathrm{Sn}, \mathrm{Al}, \mathrm{Mo}, \mathrm{Si}$ i Na. 
Wybór grupy analizowanych pierwiastków uzależniony jest od materiałów, z jakich skonstruowany jest konkretny typ silnika, i może również obejmować dodatkowo: $\mathrm{Sb}, \mathrm{Ba}, \mathrm{Cd}, \mathrm{Mg}, \mathrm{Mn}, \mathrm{Ni}, \mathrm{P}, \mathrm{Ti}$ oraz V [9]. Otrzymane wyniki badań zawartości pierwiastków są analizowane pod kątem możliwych źródeł ich pochodzenia i przyczyn ich powstania $[15,16]$.

2) Ocena zmian właściwości fizykochemicznych oleju silnikowego. Do tego celu powszechnie wykorzystywana jest uniwersalna metoda spektroskopii w podczerwieni $\mathrm{z}$ transformacją Fouriera (FTIR). Pozwala ona na analizę stopnia utlenienia oleju, zawartości sadzy, produktów zawierających siarkę, produktów nitratacji oraz zawartości w oleju silnikowym paliwa, wody i glikolu [6, 13].

3) Ocena zmian właściwości oleju silnikowego w różnych obszarach lub potwierdzenie wyników otrzymanych metodą FTIR. Do tej grupy analiz zaliczamy: liczbę kwasową, całkowitą liczbę zasadową, lepkość kinematyczną, lepkość dynamiczną w wysokich temperaturach HTHS, zawartość paliwa (etanolu) w oleju silnikowym i inne parametry. Wyniki badań analizowane są pod kątem możliwych przyczyn zmiany powyższych parametrów w czasie oraz potencjalnych skutków, jakie mogą mieć na właściwości użytkowe i eksploatacyjne oleju silnikowego.

\section{Założenia prowadzonych badań}

Podstawowym celem podjętych badań było określenie wpływu paliw etanolowych zawierających do $20 \%(\mathrm{~V} / \mathrm{V})$ etanolu na procesy degradacji smarowego oleju silnikowego, monitorowane za pomocą wybranych właściwości fizykochemicznych.

Na obiekt badań, ze względu na właściwości lepkościowe i jakościowe, wytypowano olej silnikowy o klasie lepkości SAE 5W-30 i klasie jakości ACEA A5/B5, spełniający wymagania producenta Ford WSS-M2C913-C, przeznaczony do smarowania silników samochodowych o zapło- nie iskrowym typu flex-fuel. Właściwości fizykochemiczne przedmiotowego oleju silnikowego zebrano w tablicy 1.

Eksploatację smarowego oleju silnikowego przeprowadzono na silnikowym stanowisku badawczo-testowym Ford 1.8L Duratec-HE PFI FFV (125 PS) MI4 (Euro IV), fabrycznie przystosowanym do zasilania paliwem o zawartości od 0 do $85 \%$ ( $V / V)$ etanolu (rysunek 1). Na podstawie własnego doświadczenia założono, że testy będą realizowane przez $400 \mathrm{~h}$ rzeczywistej pracy silnika, ponieważ w tym czasie nastąpi wielkokierunkowa degradacja oleju silnikowego.

Tablica 1. Właściwości fizykochemiczne nieeksploatowanego smarowego oleju silnikowego SAE 5W-30 ACEA A5/B5 oznaczone w INiG - PIB

\begin{tabular}{|c|c|c|c|}
\hline Oznaczana cecha & Metoda badania & Jednostka & $\begin{array}{l}\text { Olej świeży } \\
\text { PN/TE/0/16 }\end{array}$ \\
\hline Lepkość kinematyczna $\mathrm{w}$ temperaturze $40^{\circ} \mathrm{C}$ & PN-EN ISO 3104:2004 & $\mathrm{mm}^{2} / \mathrm{s}$ & 55,22 \\
\hline Lepkość kinematyczna w temperaturze $100^{\circ} \mathrm{C}$ & PN-EN ISO 3104:2004 & $\mathrm{mm}^{2} / \mathrm{s}$ & 9,774 \\
\hline Wskaźnik lepkości & PN-ISO 2909:2009 + Ap1:2010 & - & 164 \\
\hline Lepkość dynamiczna HTHS w temperaturze $150^{\circ} \mathrm{C}$ & PN-C-04098:1994 & $\mathrm{mPa} \cdot \mathrm{s}$ & 3,80 \\
\hline Lepkość strukturalna CCS w temperaturze $-30^{\circ} \mathrm{C}$ & PN-C-04150:2004 & $\mathrm{mPa} \cdot \mathrm{s}$ & 2800 \\
\hline Całkowita liczba zasadowa & PN-C-04163:1976 & $\mathrm{mg} \mathrm{KOH} / \mathrm{g}$ & 11,1 \\
\hline Liczba kwasowa & PN-C-04049:1988 & $\mathrm{mg} \mathrm{KOH} / \mathrm{g}$ & 2,8 \\
\hline Zawartość etanolu & $\begin{array}{c}\text { Technika wysokotemperaturowej } \\
\text { chromatografii gazowej }\end{array}$ & $\%(m / m)$ & $<0,005$ \\
\hline Zawartość osadów nierozpuszczalnych: & \multirow{3}{*}{ ASTM D 893-14 } & \multirow{3}{*}{$\%(m / m)$} & \\
\hline$-\mathrm{w}$ pentanie & & & 0,000 \\
\hline$-\mathrm{w}$ toluenie & & & 0,000 \\
\hline Zawartość sadzy & DIN 51452:1994 & $\%(m / m)$ & $<0,1$ \\
\hline Odporność na utlenianie w cienkiej warstwie & ASTM D 4742 & $\min$ & 21 \\
\hline Zawartość pierwiastków pakietowych: & \multirow{5}{*}{ ASTM D 5185-09 } & & \\
\hline - cynk & & \multirow{4}{*}{ ppm } & 902,0 \\
\hline - wapń & & & 3017,0 \\
\hline - magnez & & & 24,0 \\
\hline- fosfor & & & 674,0 \\
\hline
\end{tabular}






Rys. 1. Widok stanowiska badawczego z silnikiem

Ford 1.8L Duratec-HE PFI FFV zasilanego paliwem etanolowym E20 i smarowym olejem silnikowym SAE 5W-30 (ACEA A5/B5) (fot. INiG - PIB)

\section{Wyniki badań}

W ramach projektu przeprowadzono dwa testy na stanowisku silnikowym typu flex-fuel silnika z zapłonem iskrowym zasilanego dwoma paliwami, skomponowanymi z:

1) $80 \%(V / V)$ bazowej benzyny silnikowej $+20 \%(V / V)$ bioetanolu pierwszej generacji + pakietu dodatków uszlachetniających opracowanego w INiG - PIB,

2) $80 \%(V / V)$ bezołowiowej benzyny silnikowej (handlowa, uszlachetniona pakietem dodatków przez producenta) + $20 \%(V / V)$ bioetanolu pierwszej generacji.

Stopień degradacji smarowego oleju silnikowego był określany zarówno w czasie trwania prób silnikowych (próbki oleju pobrane po $200 \mathrm{~h}$ pracy silnika w minimalnej ilości, tak aby nie było wymagane odświeżanie całej jego objętości), jak i po zakończeniu jego eksploatacji (po $400 \mathrm{~h}$ pracy). Próbki zostały przebadane zgodnie z zakresem badań ujętym w tablicy 2 .
W tablicy 3 zestawiono wyniki oceny stanu smarowego oleju silnikowego otrzymane podczas silnikowych testów symulacyjnych.

Wybrane rezultaty analiz właściwości fizykochemicznych eksploatowanych olejów smarowych przedstawiono na rysunkach 2-13.

Przedstawione wyniki badań wskazują, że smarowy olej silnikowy, współpracując z paliwem etanolowym, utracił odpowiedni poziom właściwości użytkowych.

Naturalne, łagodne procesy utleniania oleju silnikowego spowodowały zmianę jego lepkości kinematycznej. W przypadku wszystkich przebadanych próbek oleju silnikowego oznaczono niewielki jej wzrost, tym wyższy, im dłuższy był czas eksploatacji, co przekłada się również na spadek wskaźnika lepkości. Zmiana lepkości kinematycznej oznaczonej w temperaturach $40^{\circ} \mathrm{C}$ i $100^{\circ} \mathrm{C}$ układa się w obu przypad-

Tablica 2. Metody badań stosowane do oceny zmian właściwości fizykochemicznych smarowego oleju silnikowego SAE 5W-30 podczas eksploatacji

\begin{tabular}{|l|c|}
\hline \multicolumn{1}{|c|}{ Właściwości oleju silnikowego } & Metody badań \\
\hline Lepkość kinematyczna w temperaturze $40^{\circ} \mathrm{C}$ & PN-EN ISO 3104:2004 \\
\hline Lepkość kinematyczna w temperaturze $100^{\circ} \mathrm{C}$ & PN-EN ISO 3104:2004 \\
\hline Wskaźnik lepkości & PN-ISO 2909:2009+ Ap1:2010 \\
\hline Lepkość dynamiczna w wysokich temperaturach. Metoda HTHS & PN-C-04098:1994 \\
\hline Lepkość strukturalna w niskich temperaturach. Metoda CCS & PN-C-04150:2004 \\
\hline Całkowita liczba zasadowa & PN-C-04163:1976 \\
\hline Liczba kwasowa & PN-C-04049:1988 \\
\hline Zawartość składników nierozpuszczalnych w pentanie i toluenie & ASTM D 893-14 \\
\hline Stopień oksydacji, nitratacji i sulfonowania & ASTM E 2412-10 \\
\hline Zawartość sadzy & DIN 51452:1994 \\
\hline Zawartość pierwiastków pakietowych, zużyciowych i pochodzących z zanieczyszczeń & ASTM D 5185-09 \\
\hline Zawartość etanolu & Technika wysokotemperaturowej \\
\hline Odporność na utlenianie przebiegające w cienkiej warstwie oleju & ASTM D 4742 \\
\hline
\end{tabular}


Tablica 3. Wyniki badań właściwości fizykochemicznych próbek smarowego oleju silnikowego SAE 5W-30 pobranych podczas testów w silniku typu flex-fuel

\begin{tabular}{|c|c|c|c|c|c|}
\hline Oznaczana cecha & Jedn. & $\begin{array}{l}\text { (200 h pracy) } \\
\mathrm{PN} / \mathrm{TE} / 1 / 16\end{array}$ & $\begin{array}{l}\text { (400 h pracy) } \\
\mathrm{PN} / \mathrm{TE} / 2 / 16\end{array}$ & $\begin{array}{l}\text { (200 h pracy) } \\
\mathrm{PN} / \mathrm{TE} / 3 / 16\end{array}$ & $\begin{array}{l}\text { (400 h pracy) } \\
\mathrm{PN} / \mathrm{TE} / 4 / 16\end{array}$ \\
\hline Lepkość kinematyczna w temperaturze $40^{\circ} \mathrm{C}$ & $\mathrm{mm}^{2} / \mathrm{s}$ & 59,05 & 61,70 & 59,24 & 61,76 \\
\hline Lepkość kinematyczna w temperaturze $100^{\circ} \mathrm{C}$ & $\mathrm{mm}^{2} / \mathrm{s}$ & 10,22 & 10,60 & 10,21 & 10,59 \\
\hline Wskaźnik lepkości & - & 162 & 163 & 161 & 162 \\
\hline Lepkość dynamiczna HTHS w temperaturze $150^{\circ} \mathrm{C}$ & $\mathrm{mPa} \cdot \mathrm{s}$ & 3,36 & 3,25 & - & 3,29 \\
\hline Lepkość strukturalna CCS w temperaturze $-30^{\circ} \mathrm{C}$ & $\mathrm{mPa} \cdot \mathrm{s}$ & 2900 & 3100 & - & 3300 \\
\hline Całkowita liczba zasadowa & $\mathrm{mg} \mathrm{KOH} / \mathrm{g}$ & 9,5 & 7,4 & - & 7,2 \\
\hline Liczba kwasowa & $\mathrm{mg} \mathrm{KOH} / \mathrm{g}$ & 2,9 & 5,7 & - & 6,7 \\
\hline Zawartość etanolu & $\%(m / m)$ & $<0,005$ & $<0,005$ & $<0,005$ & 0,009 \\
\hline Zawartość osadów nierozpuszczalnych: & \multirow{3}{*}{$\%(m / m)$} & & & & \\
\hline$-\mathrm{w}$ pentanie & & 0,000 & 0,008 & 0,000 & 0,004 \\
\hline$-\mathrm{w}$ toluenie & & 0,000 & 0,002 & 0,000 & 0,006 \\
\hline Stopień oksydacji & \multirow{3}{*}{$\mathrm{A} / \mathrm{cm}$} & 12,3 & 16,9 & 13,7 & 16,0 \\
\hline Stopień nitratacji & & 14,8 & 20,8 & 15,3 & 24,2 \\
\hline Stopień sulfonowania & & 13,0 & 19,4 & 12,2 & 20,4 \\
\hline Zawartość sadzy & $\%(m / m)$ & $<0,1$ & $<0,1$ & - & $<0,1$ \\
\hline Odporność na utlenianie w cienkiej warstwie & $\min$ & 14 & 3 & 11 & 9 \\
\hline \multicolumn{6}{|l|}{ Zawartość pierwiastków pakietowych: } \\
\hline - cynk & \multirow{4}{*}{ ppm } & 878,0 & 865,0 & 876,0 & 856,0 \\
\hline - wapń & & 2950,0 & 2310,0 & 2972,0 & 2322,0 \\
\hline - magnez & & 23,0 & 9,2 & 23,5 & 9,3 \\
\hline- fosfor & & 654,0 & 643,0 & 669,0 & 660,0 \\
\hline \multicolumn{6}{|l|}{$\begin{array}{l}\text { Zawartość pierwiastków zużyciowych } \\
\text { i z zanieczyszczeń: }\end{array}$} \\
\hline - żelazo & \multirow{12}{*}{ ppm } & 17,0 & 55,0 & 20,0 & 30,0 \\
\hline- glin & & $<6,0$ & $<6,0$ & $<6,0$ & $<6,0$ \\
\hline- miedź & & $<2,0$ & $<2,0$ & $<2,0$ & $<2,0$ \\
\hline - ołów & & $<10,0$ & $<10,0$ & $<10,0$ & $<10,0$ \\
\hline- bar & & $<0,5$ & $<0,5$ & $<0,5$ & $<0,5$ \\
\hline - chrom & & $<1,0$ & $<1,0$ & $<1,0$ & $<1,0$ \\
\hline- potas & & $<10,0$ & $<10,0$ & $<10,0$ & $<10$ \\
\hline - molibden & & 50,0 & 100,0 & 78,0 & 101,0 \\
\hline - sód & & $<7,0$ & $<7,0$ & 71,0 & 72,0 \\
\hline- nikiel & & $<5,0$ & $<5,0$ & $<5,0$ & $<5,0$ \\
\hline- krzem & & 170,0 & 196,0 & 184,0 & 192,0 \\
\hline - cyna & & $<10,0$ & $<10,0$ & $<10,0$ & $<10$ \\
\hline
\end{tabular}

kach w sposób analogiczny - obserwowany jest wzrost lepkości wraz ze wzrostem czasu eksploatacji. Dla próbek olejów silnikowych pobranych po $200 \mathrm{~h}$ eksploatacji silnika w warunkach testu (PN/TE/1/16 i PN/TE/2/16) wzrost lepkości kinematycznej w temperaturze $40^{\circ} \mathrm{C}$ w obu próbkach wynosił około 7\% w stosunku do wartości wyjściowej oznaczonej dla oleju nieeksploatowanego (rysunek 2). Z kolei zwiększenie lepkości kinematycznej w temperaturze $100^{\circ} \mathrm{C}$ dla tych próbek w porównaniu z wartością początkową było równe 4,5\% (rysunek 3). Dla próbek olejów silnikowych pobranych po $400 \mathrm{~h}$ pracy silnika wzrost lepkości kinematycznej w obu temperaturach był większy i wynosił dla temperatury $40^{\circ} \mathrm{C}$ około $7 \%$, a dla $100^{\circ} \mathrm{C}$ około $8,5 \%$. W obu przypadkach wzrost lepkości kinematycznej nie był wysoki, co świadczy o przebiegu naturalnych, łagodnych procesów utleniania przedmiotowego oleju silnikowego w trakcie eksplo- 
atacji, prowadzących do jego stopniowej degradacji oraz zanieczyszczenia go produktami spalania, co przekłada się na spadek wskaźnika lepkości (rysunek 4).

Dodatkowo możemy zaobserwować niewielki wzrost lepkości strukturalnej CCS oznaczonej w temperaturze $-30^{\circ} \mathrm{C}$. Wyniki dla wszystkich próbek smarowego oleju silnikowego pobranych w czasie eksploatacji mieszczą się w granicach odtwarzalności metody pomiarowej (kształtującej się na poziomie około $240 \div 250 \mathrm{mPa} \cdot \mathrm{s}$ ) (rysunek 5).

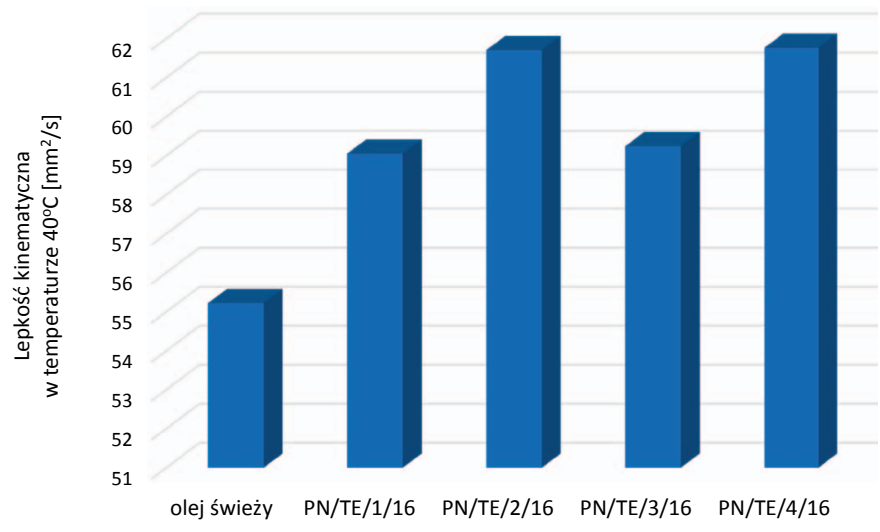

Rys. 2. Zmiana lepkości kinematycznej w temperaturze $40^{\circ} \mathrm{C}$ próbek oleju silnikowego SAE $5 \mathrm{~W}-30$

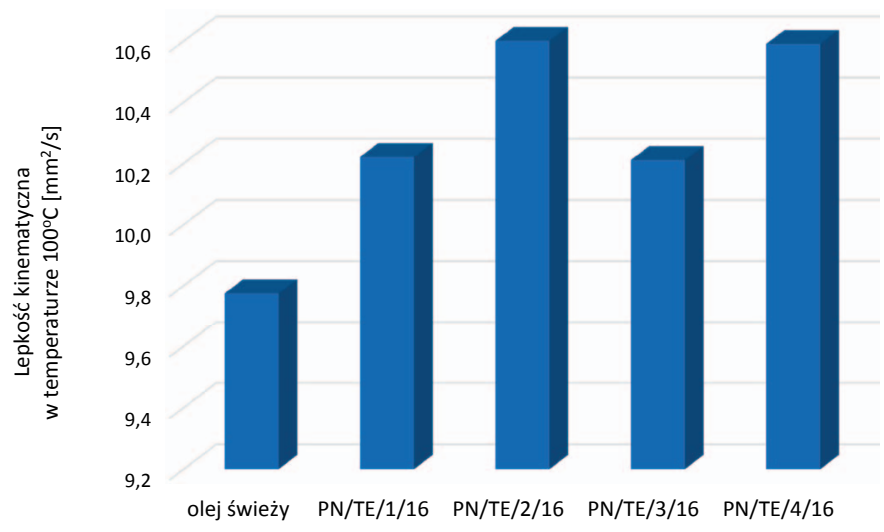

Rys. 3. Zmiana lepkości kinematycznej w temperaturze $100^{\circ} \mathrm{C}$ próbek oleju silnikowego SAE 5W-30

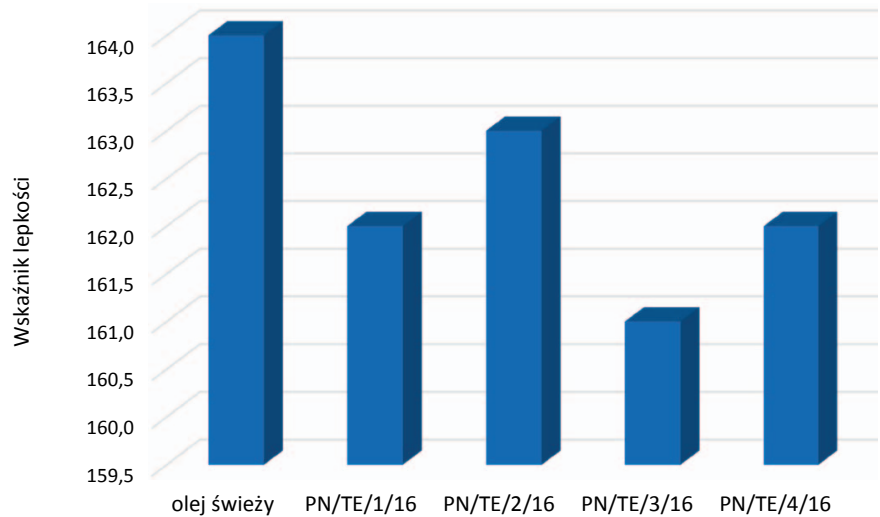

Rys. 4. Zmiana wskaźnika lepkości próbek oleju silnikowego SAE 5W-30



Rys. 5. Zmiana lepkości strukturalnej CCS w temperaturze $-30^{\circ} \mathrm{C}$ próbek oleju silnikowego SAE $5 \mathrm{~W}-30$

W miarę wzrostu cieplnych i mechanicznych obciążeń silnika spalinowego, a także $\mathrm{z}$ rozpowszechnieniem olejów wielosezonowych, obejmujących coraz szerszy zakres klas lepkości, większą wagę przywiązuje się do rzeczywistej lepkości smarowego oleju silnikowego w węzłach tarcia silnika. Lepkość dynamiczna HTHS badanych próbek oleju podczas testów silnikowych nie przekraczała wartości granicznej $(2,9 \mathrm{mPa} \cdot \mathrm{s})$, co gwarantowało utrzymanie odpowiedniej wytrzymałości filmu smarowego nawet w warunkach wysokiej temperatury i przy dużych szybkościach ścinania (rysunek 6).

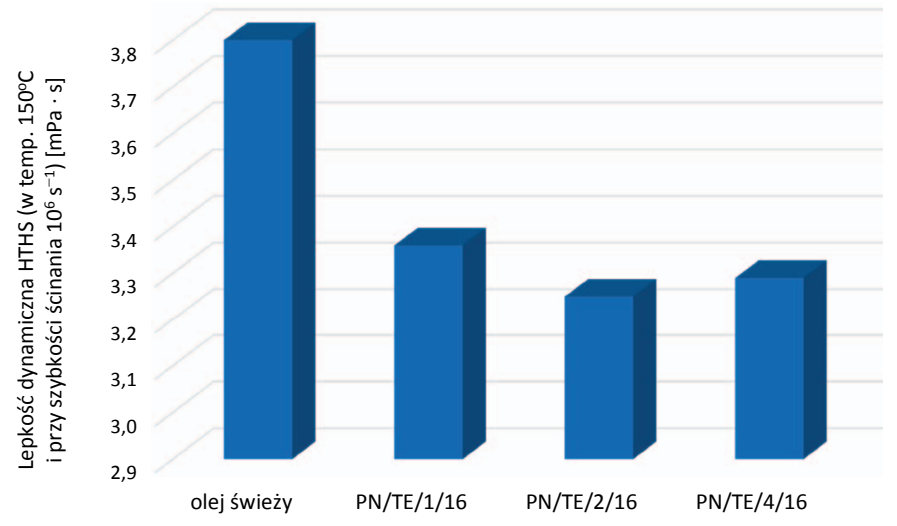

Rys. 6. Zmiana lepkości dynamicznej HTHS próbek oleju silnikowego SAE 5W-30

Produkty utleniania przedmiotowego silnikowego oleju smarowego, jak i innych procesów jego degradacji doprowadziły do znacznego spadku całkowitej liczby zasadowej. Dla próbki oleju pobranej po 200 h eksploatacji obserwujemy jej spadek o około $14 \%$ w stosunku do oleju nieeksploatowanego (PN/TE/1/16), a w przypadku próbek wziętych po $400 \mathrm{~h}$ - o $33 \div 35 \%$ (przyjęty poziom ostrzegawczy dla tego parametru wynosi około 15\%, a krytyczny - 25\%) [12]. Wskazuje to na znaczne obniżenie potencjału myjąco-dyspergującego i rezerwy alkalicznej oleju, istotnej ze względu na ko- 
nieczność neutralizacji produktów kwaśnych, w tym głównie kwasów nieorganicznych, pochodzących z procesów spalania paliwa oraz częściowo $\mathrm{z}$ utleniania oleju i powodujących rozwój procesów korozyjnych na powierzchniach wewnętrznych elementów silnika. Potwierdzeniem tych zjawisk jest nie tylko spadek całkowitej liczby zasadowej, ale również duży wzrost liczby kwasowej (dla próbki pobranej po $200 \mathrm{~h}$ wzrost ten wynosi około $3,5 \%$, a dla próbek uzyskanych po $400 \mathrm{~h}$ pracy jest dwukrotnie wyższy od wartości wyjściowej) - rysunek 7.



Rys. 7. Zmiana całkowitej liczby zasadowej i liczby kwasowej próbek oleju silnikowego SAE 5W-30

W czasie eksploatacji przedmiotowego smarowego oleju silnikowego na skutek zachodzących procesów starzenia obserwuje się także wzrost zawartości produktów reakcji utleniania, nitratacji oraz sulfonowania, który jest również związany z czasem eksploatacji. Najwyższe zwiększenie produktów utleniania zaobserwowano dla próbki $\mathrm{PN} / \mathrm{TE} / 2 / 16$, a produktów nitratacji i sulfonowania - dla PN/TE/4/16 (rysunek 8).

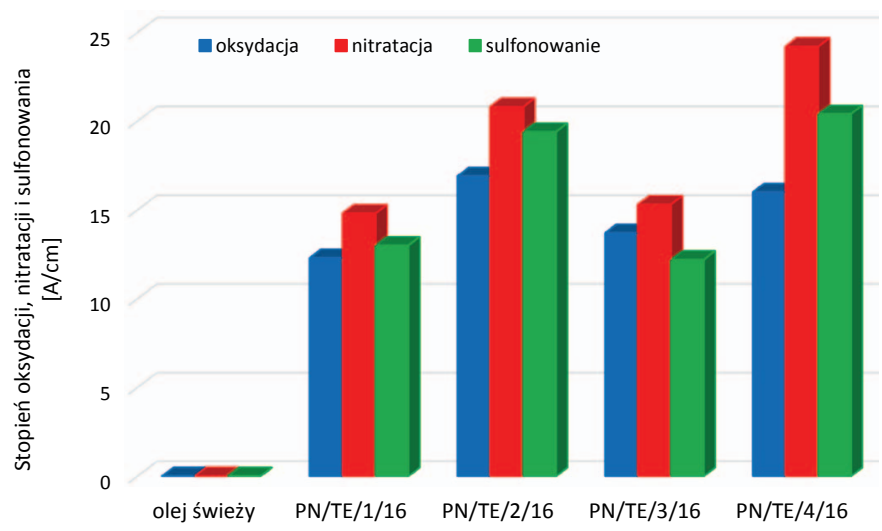

Rys. 8. Zmiana stopnia oksydacji, nitratacji i sulfonowania próbek oleju silnikowego SAE 5W-30
Naturalna odporność na utlenianie bazy olejowej, wzmocniona zastosowanym w pakiecie dodatkiem przeciwutleniającym, uległa znacznemu obniżeniu, o czym świadczą wyniki badania odporności na utlenianie w cienkiej warstwie.

Zmniejszenie się odporności na utlenianie wiąże się z czasem eksploatacji - im jest on dłuższy, tym większa utrata odporności. Dla próbek pobranych po $200 \mathrm{~h}$ pracy spadek ten wynosi około $50 \%$ w stosunku do wartości wyjściowej (poziom krytyczny dla tego parametru wynosi $25 \%$ ), a po $400 \mathrm{~h}$ doszło do niemal całkowitego wyczerpania się dodatków przeciwutleniających (rysunek 9) [12].

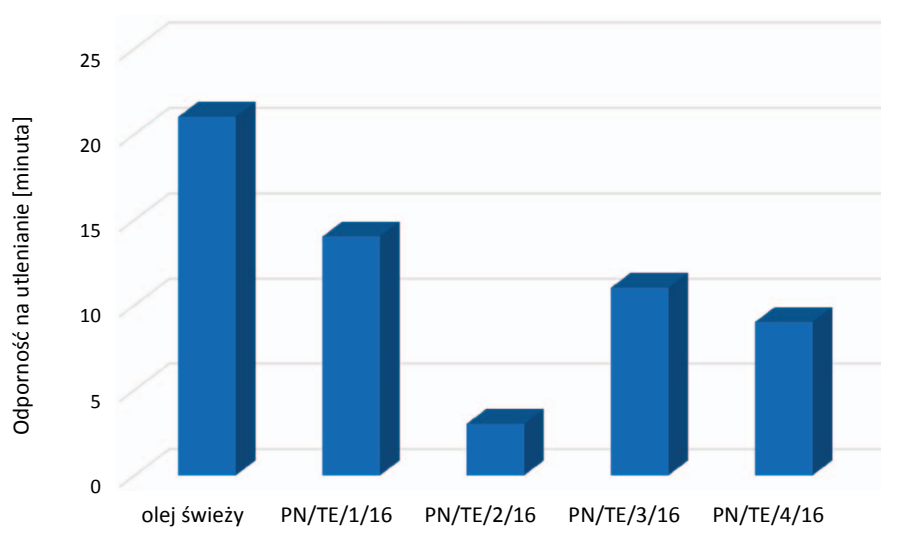

Rys. 9. Zmiana odporności na utlenianie próbek oleju silnikowego SAE 5W-30

Na podstawie wyników oznaczenia zawartości pierwiastków można określić stopień wyczerpywania się poszczególnych dodatków uszlachetniających, jak również dokonywać oceny stopnia zużycia elementów silnika, w którym eksploatowany jest olej silnikowy. Na ich podstawie uzyskujemy także informację odnośnie do stopnia zanieczyszczenia oleju smarowego substancjami pochodzącymi spoza układu (tj. pył czy kurz)

W przypadku pierwiastków pakietowych ( $\mathrm{Zn}, \mathrm{Ca}, \mathrm{P}, \mathrm{Mg}$ ) obserwujemy ich nieznaczny spadek wraz z wydłużaniem się czasu eksploatacji, co świadczy o naturalnym i stopniowym wyczerpywaniu się pakietu dodatków uszlachetniających dla wszystkich próbek oleju smarującego SAE 5W-30 (rysunki 10, 11).

W przypadku pierwiastków pochodzących ze zużycia elementów silnika i zanieczyszczenia układu zasilania silnika produktami z zewnątrz - zaobserwowano wzrost zawartości molibdenu dla próbek oleju PN/TE/2/16 oraz PN/TE/4/16 (o 50\% w stosunku do poziomu oznaczonego w oleju nieeksploatowanym) i nieznaczny wzrost zawartości żelaza, jak również zwiększenie się zawartości krzemu (rysunki 12 i 13). 




Rys. 10. Zmiana zawartości wapnia, fosforu i cynku w próbkach oleju silnikowego SAE 5W-30



Rys. 12. Zmiana zawartości pierwiastków zużyciowych w próbkach oleju silnikowego SAE 5W-30

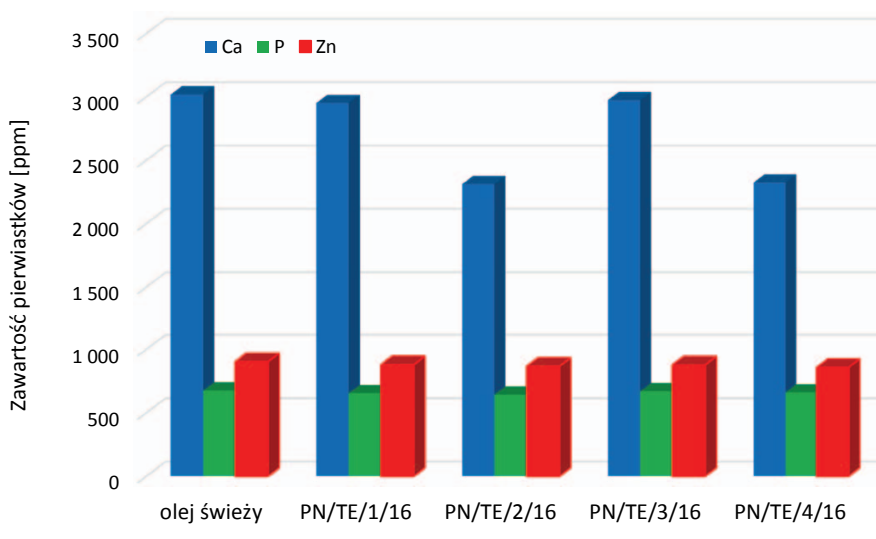

Rys. 11. Zmiana zawartości magnezu w próbkach oleju silnikowego SAE 5W-30

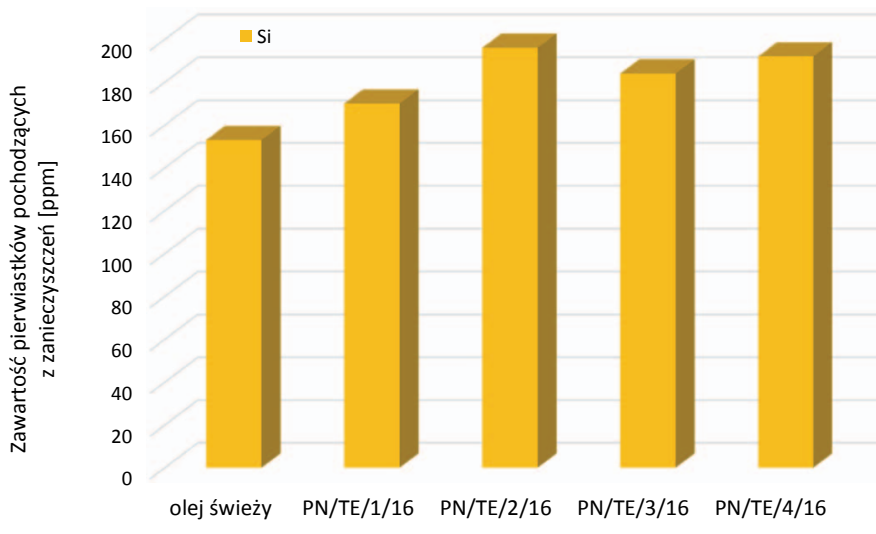

Rys. 13. Zmiana zawartości pierwiastków z zanieczyszczeń w próbkach oleju silnikowego SAE 5W-30

\section{Wnioski}

1. Niezależnie od rodzaju zastosowanego paliwa etanolowego zasilającego silnik flex-fuel smarowy olej silnikowy Ford Formuła F w klasie lepkości SAE 5W-30 utrzymywał porównywalny poziom degradacji po przebiegu $200 \mathrm{~h} \mathrm{i} 400 \mathrm{~h}$.

2. We wszystkich przypadkach nastąpiła degradacja oleju silnikowego, na co wskazuje wyczerpywanie dodatku przeciwutleniającego, czego potwierdzeniem jest znaczny spadek odporności na utlenianie oraz wzrost produktów powstałych na skutek reakcji utleniania określony jako stopień oksydacji.

3. W wyniku degradacji smarowego oleju silnikowego w trakcie eksploatacji zwiększyła się w dużym stopniu ilość substancji o charakterze kwaśnym, a odzwierciedle- niem tego zjawiska jest wzrost liczby kwasowej, a także bardzo duży spadek całkowitej liczby zasadowej (rezerwy alkalicznej), poniżej poziomu krytycznego, wynoszącego maksymalnie $25 \%$ od wartości oznaczonej dla oleju świeżego wspomnianej klasy lepkościowej.

4. Zaobserwowano niewielki wzrost zawartości pierwiastków zużyciowych i pochodzących z zanieczyszczeń elementów silnika, ale kształtowała się ona na dopuszczalnym poziomie.

5. Wytypowane do oceny stopnia degradacji oleju silnikowego SAE 5W-30 metody badawcze pozwoliły monitorować trendy zmian jego właściwości użytkowych w trakcie eksploatacji w silniku.

Prosimy cytować jako: Nafta-Gaz 2017, nr 2, s. 109-118, DOI: 10.18668/NG.2017.02.06

Artykuł nadesłano do Redakcji 30.11.2016 r. Zatwierdzono do druku 16.01.2017 r.

Artykuł powstał na podstawie pracy statutowej pt. Wpływ oddziaływania paliw z różna zawartościa bioetanolu na degradacje smarowego oleju silnikowego - praca INiG - PIB na zlecenie MNiSW; nr zlecenia: 0082/TE/16, nr archiwalny: TE-4101-82/16. 


\section{Literatura}

[1] Bergström K., Melin S.A., Coleman J.: The New ECOTEC Turbo BioPower Engine from GM Powertrain - Utilizing the Power of Nature's resources. 28th Internationales Wiener Motorensymposium, 2007.

[2] Jakóbiec J.: Olej silnikowy jako element konstrukcyjny silnika spalinowego. Nowoczesny Warsztat 2005, nr 6, s. 32-39.

[3] Jakóbiec J.: Rola i znaczenie badań eksploatacyjnych w ocenie paliw silnikowych i środków smarowych. Nafta-Gaz 2005 , nr 4, s. 171-177.

[4] Jakóbiec J.: Rozwój konstrukcji silników spalinowych wyznacznikiem postępu technologii olejów smarowych. Nowoczesny Warsztat 2010, nr 7, s. 38-40.

[5] Jakóbiec J., Gis W., Wysopal G.: Kierunki rozwoju technologii olejów silnikowych z uwzględnieniem paliw alternatywnych. Silniki Spalinowe 2012, nr 1, s. 101-104.

[6] Jakóbiec J., Janik R., Olszewski W.: Ocena zmian właściwości użytkowych oraz składu chemicznego olejów smarowych $w$ trakcie eksploatacji $w$ aspekcie zagrożenia dla środowiska naturalnego. II Międzynarodowa Konferencja Naukowo-Techniczna RECYKLING 2002, s. 222-231.

[7] Jakóbiec J., Mazanek A.: Procesy zachodzace w oleju silnikowym w czasie pracy. Nowoczesny Warsztat 2009, nr 5, s. 14-16.

[8] Jakóbiec J., Urzędowska W., Wysopal G., Pałuchowska M.: Badania współdziałania benzyn silnikowych zawierajacych bioetanol oraz dodatki uszlachetniajace z olejami silnikowy$m i$. Praca niepublikowana, Instytut Technologii Nafty, Kraków 2005.

[9] Jakóbiec J., Urzędowska W., Wysopal G.: Badania eksplo- atacyjne oleju silnikowego klasy SL/CF SAE 5W/40. Praca niepublikowana - Instytut Technologii Nafty, Kraków 2005.

[10] Jakóbiec J., Wądrzyk M.: Wpływ oleju smarujacego i biopaliwa na stan techniczny silnika o zapłonie samoczynnym. VII Konferencja Naukowo-Techniczna LOGITRANS 2010 , s. $1651-1666$.

[11] Jakóbiec J., Wysopal G.: Produkty degradacji oleju smarujacego - wpływ na zużycie i zanieczyszczenie silnika w okresie eksploatacji. Nowoczesny Warsztat 2005, nr 6, s. 42-43.

[12] Majka W., Farbiszewski P.: Diagnostyka olejowa w praktyce - warsztaty. Ustroń, październik 2011.

[13] Price M.J.: The Development of Specifications for Automotive Fuels. Biuletyn ITN 2003, nr 1.

[14] Rigol S.: Monitoring Concept to Detect Engine Oil Condition Degradations to Support a Reliable Drive Operation. A thesis submitted in partial fulfilment of the requirements of the University of East London for the degree of Doctor of Philosophy, September 2011.

[15] Stępień Z.: Skonstruowanie silnikowego stanowiska badawczego do oceny benzyn silnikowych zawierajacych w swym składzie do $85 \%(V / V)$ etanolu. Działalność statutowa, nr zlec. 0108/TE/2010, s. 9-13.

[16] Urzędowska W., Stępień Z.: Oddziaływanie paliwa na zmiany właściwości użytkowych oleju smarowego w silniku z ZI typu Flex Fuel. Nafta-Gaz 2012, nr 6, s. 377-387.

[17] Urzędowska W., Stępień Z.: Wybrane zagadnienia dotyczace zmian wtaściwości silnikowego oleju smarowego w eksploatacji. Nafta-Gaz 2012, nr 12, s. 1102-1110.



Mgr inż. Magdalena ŻÓŁTY

Specjalista badawczo-techniczny w Zakładzie Oceny Właściwości Eksploatacyjnych; kierownik Laboratorium Badań Właściwości Użytkowych.

Instytut Nafty i Gazu - Państwowy Instytut Badawczy ul. Lubicz 25 A, 31-503 Kraków

E-mail: magdalena.zolty@inig.pl

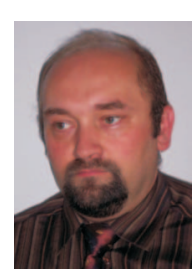

Mgr inż. Dariusz SACHA

Starszy specjalista badawczo-techniczny w Zakładzie Oceny Właściwości Eksploatacyjnych.

Instytut Nafty i Gazu - Państwowy Instytut Badawczy

ul. Lubicz 25 A

31-503 Kraków

E-mail: dariusz.sacha@inig.pl 